\title{
TEPHRA OCCURRENCE IN ALASKA: A MAP-BASED COMPILATION OF STRATIGRAPHIC TEPHRA DATA
}

Anna K. Worden, Janet R. Schaefer, and Katherine M. Mulliken

Miscellaneous Report 165

September 2018

STATE OF ALASKA

DEPARTMENT OF NATURAL RESOURCES

DIVISION OF GEOLOGICAL \& GEOPHYSICAL SURVEYS

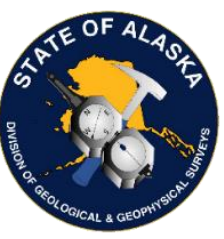




\author{
STATE OF ALASKA \\ Bill Walker, Governor
}

DEPARTMENT OF NATURAL RESOURCES

Andrew T. Mack, Commissioner

DIVISION OF GEOLOGICAL \& GEOPHYSICAL SURVEYS

Steve Masterman, State Geologist \& Director

Publications produced by the Division of Geological \& Geophysical Surveys are available to download from the DGGS website (dggs.alaska.gov). Publications on hard-copy or digital media can be examined or purchased in the Fairbanks office:

\title{
Alaska Division of Geological \& Geophysical Surveys (DGGS)
}

3354 College Road | Fairbanks, Alaska 99709-3707

Phone: 907.451 .5010 | Fax 907.451.5050

dggspubs@alaska.gov | dggs.alaska.gov

DGGS publications are also available at:

Alaska State Library, Historical

Collections \& Talking Book Center

395 Whittier Street

Juneau, Alaska 99801

Alaska Resource Library and

Information Services (ARLIS)

3150 C Street, Suite 100

Anchorage, Alaska 99503

\section{Suggested citation:}

Worden, A.K., Schaefer, J.R., and Mulliken, K.M. 2018, Tephra occurrence in Alaska: a map-based compilation of stratigraphic tephra data: Alaska Division of Geological \& Geophysical Surveys Miscellaneous Publication 165, 19p.

http://doi.org/10.14509/30059
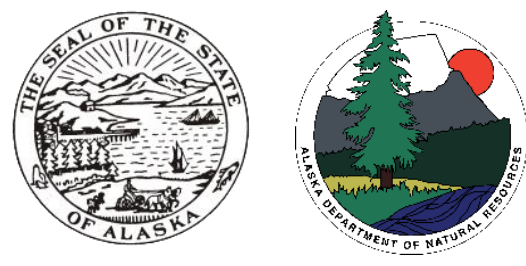



\section{Contents}

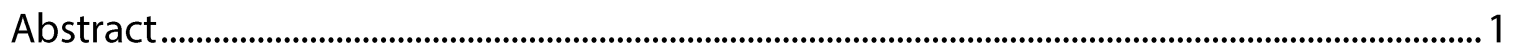

Introduction............................................................................................................................ 1

Tephra Occurrence Database ...........................................................................................................

Database Overview …………………………………………................................................

Stratigraphic Station Information.........................................................................................

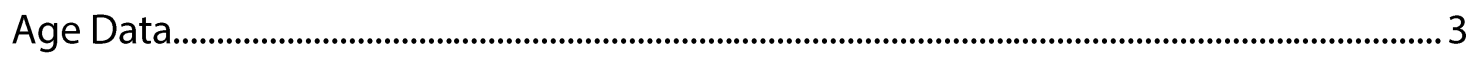

Dating Methods Used .......................................................................................................

Recurrence Interval and Frequency Calculations..................................................................

Interactive Tephra Occurrence Map.........................................................................................6

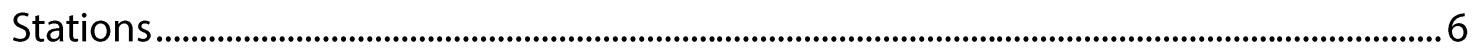

Spatial Frequency Grid ...............................................................................................................

How to use this map product:.............................................................................................................

To get data for a specific station or grid square ……………………………………………....

future goals and database additions:...............................................................................................

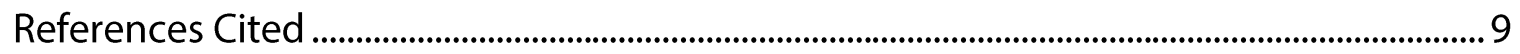

Appendix 1: References for Tephra Occurrence Data ………………….................................... 9

\section{Figures}

Figure 1: Tephra occurrence information compiled from investigations of geologic deposits throughout Alaska. Inset map (lower panel) highlights the Cook Inlet region. Colored dots represent the number of discrete tephra layers seen at each location. Colored grid indicates the number of tephra footprints recorded for the area................. 2 Figure 2. Location of the HTML popup tool (red box) and an example of data display for stations and grid squares.

\section{Tables}

Table 1. Overview of data included in full tephra occurrence database. ............................. 4

Table 2. Map elements included in GIS product........................................................................ 


\section{TEPHRA OCCURRENCE IN ALASKA: A MAP-BASED COMPILATION OF STRATIGRAPHICTEPHRA DATA}

Anna K. Worden ${ }^{1}$, Janet R. Schaefer ${ }^{1}$, and Katherine M. Mulliken ${ }^{1}$

\section{ABSTRACT}

The principal hazard associated with future explosive eruptions of Alaska volcanoes is the generation of volcanic ash clouds which are explosively blasted high into the atmosphere and then drift away from the volcano with the wind. The fragments in the ash cloud (tephra) vary in size and the heavier particles fall near the source while finer particles travel downwind. This transported tephra will fall out of the cloud and accumulate on surfaces and structures, contaminate water sources, and infiltrate electronics and motors. The weight of significant accumulations may collapse structures and cause other damage. Chronic exposure to ash may be a significant public health hazard. This publication presents the frequency and location of tephra fall throughout Alaska and into the Yukon Territory of Canada, resulting from eruptions of Alaska volcanoes from the Pleistocene to the present.

The tephra occurrence map facilitates better visualization of areas in Alaska with past occurrences of ashfall. The map is a useful indicator of regional potential ashfall hazards.

\section{INTRODUCTION}

Hazards from airborne ash and ashfall can impact communities near volcanoes as well as those tens to hundreds of miles away. Records of past eruptions and ashfall occurrences can aid in the preparation and mitigation of hazards associated with future eruptions. The tephra occurrence map is an informative tool used for visualization of tephra records in Alaska. It is the summation of literature and field data review for tephra dispersion information covering the State of Alaska and parts of the Yukon Territory of Canada.

This map synthesizes over 1200 stratigraphic columns located throughout Alaska and the Yukon Territory of Canada (Figure 1). The stratigraphic data is represented as points, conserving information about the deposits at each location. In addition to the stratigraphic station metadata, information about the geographic extent of ashfall events is also included, as well as a grid map which represents the spatial extent and frequency of ashfall over the state. This data is intended for use and visualization in ArcGIS.

This document explains how tephra data was obtained, the interpretation and calculations applied to the data and provides a guide on utilizing the tephra occurrence map.

In this document, the terms tephra and ash may be used interchangeably.

Tephra: Any type of rock fragment that is forcibly ejected from the volcano during an eruption.

Ash: Fine fragments (less than 2 millimeters across) of lava or rock formed in an explosive volcanic eruption.

\footnotetext{
${ }^{1}$ Alaska Division of Geological \& Geophysical Surveys, 3354 College Rd., Fairbanks, Alaska 99709-3707
} 


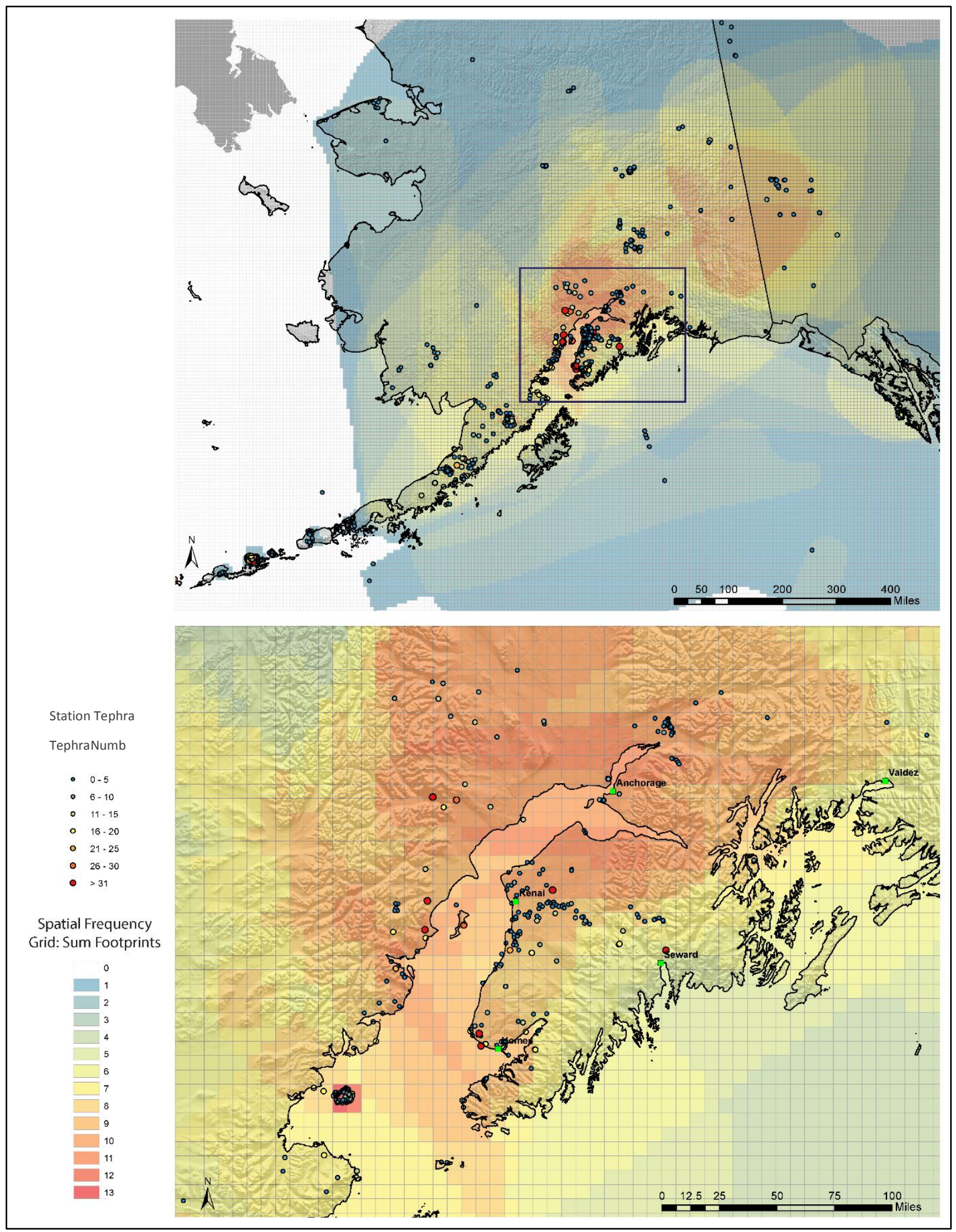

Figure 1: Tephra occurrence information compiled from investigations of geologic deposits throughout Alaska. Inset map (lower panel) highlights the Cook Inlet region. Colored dots represent the number of discrete tephra layers seen at each location. Colored grid indicates the number of tephra footprints recorded for the area. 


\section{TEPHRA OCCURRENCE DATABASE Database Overview}

An Excel spreadsheet provides all tabular data used to populate the Stations point layer in the Tephra Occurrence Geospatial Database and derivative map product. The information contained in the spreadsheet is summarized in Table 1 and includes the location of the station, information about the publication that data were derived from, a count of tephra occurrence at each station, as well as any age data and subsequent calculations of recurrence intervals.

\section{Stratigraphic Station Information}

The stations dataset within the geodatabase presents the synthesis of over 1200 stratigraphic columns located throughout Alaska and parts of the Yukon Territory of Canada, originally published in 140 references. Unpublished tephra count data by Alaska Volcano Observatory (AVO) staff is also included for the Dutch Harbor/Unalaska region (Makushin volcano, J. Schaefer, written commun.) and the Lower Cook Inlet region (K. Wallace and K. Mulliken, written commun.). Although some stations and basic information were queried from the Alaska Volcano Observatory's (AVO) Geologic Database of Information on Volcanoes in Alaska (GeoDIVA) (Cameron, 2004), an additional 604 stations were added from original references. Primary source documents were also used to compile stratigraphic information not already present in GeoDIVA, including tephra count, stratigraphic section age information, and age calculations, and this new compilation has been entered into the larger GeoDIVA database.

TephraNumb is the total number of discrete ash fall layers reported per station. For stations proximal to a volcanic vent, a single "tephra" may include multiple layers of products erupted during a single eruptive event. These proximal deposit packages are counted as single tephra events. For more distal deposits, layers tend to be thinner and separated by non-volcanic units such as soil, sands, peat, and clay. Stations without tephra layers are not included in this publication but are available upon request (geodiva@avo.alaska.edu).

\section{Age Data}

Tephra relative or direct ages and age dating methods were compiled for publications that included age data and presented on a per-station basis.

\section{Dating Methods Used}

Calibrated Radiocarbon: calibrated radiocarbon ages reported as calendar ages. These ages were either reported in the publication as calibrated or were calibrated during the creation of this report using Oxcal 4.3 (online version) with the InCal13 terrestrial calibration curve. (Ramsey, 2009; Reimer and others, 2013).

Uncalibrated radiocarbon: radiocarbon ages from publications that gave an uncalibrated age without the necessary metadata needed to produce a calibrated radiocarbon age. 
Correlation: an age is reported with a correlation method when a tephra was chemically or visually correlated to a tephra of known age. For tephras resulting from a historically observed eruption, the date of the eruption (year C.E.) is given and the age is marked as an observed eruption.

Less common dating methods in this compilation include: Age Models, K-Ar and ${ }^{40} \mathrm{Ar} /{ }^{39} \mathrm{Ar}$, Thermoluminescence, Amino Acid Geochronology, Infrared Stimulated Luminescence, Zircon Dating, Teledyne Isotope Analysis, and Glass Fission-Track Dating. See individual publications (Appendix 1) for more information on dating methodologies.

\section{Recurrence Interval and Frequency Calculations}

For each station with reported age information, an average minimum recurrence interval was calculated. The recurrence interval represents the average number of years elapsed between tephra depositions. For example, a station at Andrew Lake contained 18 tephra layers and a maximum oldest tephra age of 7500 years before present ( $\mathrm{yr} \mathrm{BP}$ ). This information provides a tephra recurrence interval of 417 years. That is, approximately every 417 years it can be expected that 1 tephra will fall in that area (Krawiec, and others, 2013). This recurrence interval is both an approximation and a minimum value, as we only have a minimum count for the possible number of tephras that have fallen and subsequently been preserved in an area and the oldest age data is often not directly correlated to the lowest tephra layer (instead being attributed to layers found below the tephra). Smaller ash fall events can occur without preservation in the geologic record.

Similarly, a tephra frequency was calculated and reports the number of tephra layers per 1000 years. This calculation uses the same information as described above and serves as an alternate method of displaying the expected frequency of tephra producing eruptions.

Table 1. Overview of data included in full tephra occurrence database.

\begin{tabular}{|c|c|}
\hline $\begin{array}{l}\text { Column/Field } \\
\text { Heading }\end{array}$ & Description \\
\hline CitationID & Citation ID assigned to the publication in the AVO reference database, GeoDIVA. \\
\hline Author & $\begin{array}{l}\text { The author of the publication used for the data. This is not necessarily the } \\
\text { geologist who visited the section. }\end{array}$ \\
\hline StationID & $\begin{array}{l}\text { Unique ID number assigned to the station for reference in AVO's GeoDIVA } \\
\text { database. }\end{array}$ \\
\hline Lat_nad83 & Latitude of station in decimal degrees, NAD 83 datum. \\
\hline Long_nad83 & Longitude of the station in decimal degrees, NAD 83 datum. \\
\hline Location & $\begin{array}{l}\text { Information on how the location of the station was obtained. If the station was } \\
\text { queried from GeoDIVA, coordinates are as found in GeoDIVA. If the station did not } \\
\text { previously exist in GeoDIVA, the location is either from specific coordinates given } \\
\text { in the text or derived by georeferencing a location map included in the } \\
\text { publication. }\end{array}$ \\
\hline
\end{tabular}




\begin{tabular}{|c|c|}
\hline $\begin{array}{l}\text { Column/Field } \\
\text { Heading }\end{array}$ & Description \\
\hline Station & Station name as represented in GeoDIVA or in the preliminary publication. \\
\hline TephraNumb & $\begin{array}{l}\text { Number of discrete tephra deposits within a stratigraphic section. In some cases } \\
\text { with very high tephra counts (and often very thin tephras), the number of discrete } \\
\text { tephras was obtained from the text of the publication. This is considered a } \\
\text { minimum number of events, as erosion and other natural processes can } \\
\text { sometimes destroy deposited tephra layers. }\end{array}$ \\
\hline Thickness & $\begin{array}{l}\text { Denotes (yes or no) whether stratigraphic thickness information was included in } \\
\text { the source publication (not necessarily corresponding to a tephra layer). No } \\
\text { numerical thickness data has been compiled at this time. }\end{array}$ \\
\hline LowerAge & $\begin{array}{l}\text { This field contains the initial ages taken directly from the publication. These ages } \\
\text { may be calibrated (if so, the age remains the same when moved to the } \\
\text { appropriate field). Information from this column is parsed into the appropriate } \\
\text { age column in the spreadsheet. Numbers in parentheses refer to a calendar year. } \\
\text { Numbers not in parentheses are yr BP. If the value is null, it indicates that there is } \\
\text { no reported tephra at the station. If the value is "unspecified", it indicates that } \\
\text { there is tephra recorded at the station, but no age data. }\end{array}$ \\
\hline OldestDate & $\begin{array}{l}\text { If the oldest tephra in the sequence is the result of a specific historic eruption, the } \\
\text { date of that event is entered here. These dates are entered in years C.E. }\end{array}$ \\
\hline OldestAge & Reported ages for the oldest (lowest) tephra in the section, in yr BP. \\
\hline AgeYrBPmax & $\begin{array}{l}\text { For ages with an error margin, this field is the maximum (oldest) age for the } \\
\text { lowest tephra. }\end{array}$ \\
\hline AgeYrBPmin & $\begin{array}{l}\text { For ages with an error margin, this field is the minimum (youngest) age for the } \\
\text { lowest tephra. }\end{array}$ \\
\hline Confidence & Some calibrations report a percentage confidence interval, typically 1-2 sigma. \\
\hline MedLowAge & $\begin{array}{l}\text { For radiocarbon ages that were calibrated as part of this work, the calculated } \\
\text { median age of the oldest/lowest tephra is presented here in yr BP. }\end{array}$ \\
\hline Method & $\begin{array}{l}\text { Indicates dating method for reported oldest ages. } \\
\text { * indicates ages calibrated for this study. }\end{array}$ \\
\hline Recurrence & $\begin{array}{l}\text { The minimum recurrence interval indicates the average number of years between } \\
\text { tephra fall events (yrs/ } 1 \text { tephra). This is calculated by dividing the oldest age of } \\
\text { tephra by the number of tephras in the section. This is a minimum recurrence } \\
\text { interval because the number of tephra layers in a section is considered a } \\
\text { minimum number of events. }\end{array}$ \\
\hline FreqTephra & $\begin{array}{l}\text { The frequency of tephra occurrence, calculated by dividing the number of tephra } \\
\text { layers by the maximum tephra age. This is reported in tephra/ } 1000 \text { years. This } \\
\text { field is based on ages provided in publication. }\end{array}$ \\
\hline
\end{tabular}




\begin{tabular}{|c|l|}
\hline $\begin{array}{c}\text { Column/Field } \\
\text { Heading }\end{array}$ & \multicolumn{1}{c|}{ Description } \\
\hline AgeComment & $\begin{array}{l}\text { Additional information about the ages of samples, including dating techniques, } \\
\text { calibration details, tephra identification, source eruptions, and chronologic } \\
\text { sequences. }\end{array}$ \\
\hline GenComment & $\begin{array}{l}\text { General comments about the station or specific layers within a stratigraphic } \\
\text { column. Some age or identifying information may also be included here. }\end{array}$ \\
\hline Reference & Reference for the publication containing original station, sample and age data. \\
\hline
\end{tabular}

\section{INTERACTIVE TEPHRA OCCURRENCE MAP}

The tephra occurrence map is in ArcGIS format and contains the collected data for individual stations, tephra distribution, and geographical and population information for Alaska and the Yukon Territory. Data layers included in the map are described in Table 2.

\section{Stations}

The map shows the point locations of all stratigraphic sections with reported tephra. The attributes of the Stations feature class mirror the field information provided in Table 1 (this document). Station icons depict tephra count with both size and color gradation - larger symbols in warmer colors indicate higher tephra count values at a station.

\section{Spatial Frequency Grid}

Mulliken and others (2018) published a digital compilation of tephra occurrence and dispersion data for the State of Alaska. The Mulliken and others (2018) publication contains tephra "footprint" polygons for those eruptions with published distribution data. These footprints represent a maximum spatial distribution for each eruption. To assist in gauging tephra fall frequency for areas without stratigraphic sections, we used Mulliken and others (2018) publication to derive a spatial tephra frequency grid for the State of Alaska, showing the number of ash footprint polygons overlaying 10 $\mathrm{km}$ by $10 \mathrm{~km}$ grid squares. The Spatial Frequency Grid polygon feature class contains identifying grid numbers and values for the sum of the footprints (Sum Footprints: reports the number of overlapping tephra footprints that fall within that grid square). This derived grid product contains only tephrafall deposits and eruptions with existing published information on distribution and is, therefore, a minimum estimate of past tephra fall occurrence.

Table 2. Map elements included in GIS product.

\begin{tabular}{|c|c|c|c|}
\hline Layer & Description & $\begin{array}{l}\text { Default } \\
\text { On/Off }\end{array}$ & $\begin{array}{c}\text { Data Source } \\
\text { (date obtained) }\end{array}$ \\
\hline AKCoast & Alaska coastline in NAD 83 datum & On & $\begin{array}{l}\text { http://www.asgdc.state.a } \\
\text { k.us/\#56 (2018) }\end{array}$ \\
\hline $\begin{array}{l}\text { Populated } \\
\text { Places }\end{array}$ & $\begin{array}{l}\text { Point feature class of cities, towns, and } \\
\text { other populated places in Alaska. }\end{array}$ & Off & $\underline{\text { http://www.asgdc.state.a }}$ \\
\hline
\end{tabular}




\begin{tabular}{|c|c|c|c|}
\hline Layer & Description & $\begin{array}{l}\text { Default } \\
\text { On/Off }\end{array}$ & $\begin{array}{c}\text { Data Source } \\
\text { (date obtained) }\end{array}$ \\
\hline Stations & $\begin{array}{l}\text { Point feature class of location and tephra } \\
\text { information for stratigraphic sections. } \\
\text { Data included in this layer are } \\
\text { summarized in Table } 1 .\end{array}$ & On & This report \\
\hline $\begin{array}{c}\text { Spatial } \\
\text { Frequency Grid }\end{array}$ & $\begin{array}{l}\text { Gridded polygon feature class containing } \\
\text { information about the number of tephras } \\
\text { overlapping within each } 10 \times 10 \mathrm{~km} \text { grid } \\
\text { square. Reports Sum Footprints for each } \\
\text { grid square. }\end{array}$ & On & $\begin{array}{l}\text { Derived from Mulliken } \\
\text { and others (2018) }\end{array}$ \\
\hline $\begin{array}{l}\text { DEM NAD83 } \\
300 m\end{array}$ & $\begin{array}{l}\text { NAD } 83 \text { datum Digital Elevation Model } \\
\text { (DEM). Digital image used in USGS Map I- } \\
2585 \text { derived from digital elevation model } \\
\text { 300m mosaic for Alaska. }\end{array}$ & On & $\begin{array}{l}\frac{\text { https://agdc.usgs.gov/dat }}{\text { a/usgs/erosafo/300m/300 }} \\
\underline{\text { m.html (2018) }}\end{array}$ \\
\hline $\begin{array}{l}\text { Alaska Tephra } \\
\text { Footprints }\end{array}$ & $\begin{array}{l}\text { Polygons representing the maximum } \\
\text { spatial distribution of tephra for each } \\
\text { eruption. Note that this is only available } \\
\text { for those deposits with existing published } \\
\text { information on distribution. }\end{array}$ & Off & $\begin{array}{l}\text { Mulliken and others } \\
\text { (2018) }\end{array}$ \\
\hline
\end{tabular}

\section{HOW TO USE THIS MAP PRODUCT:}

\section{To get data for a specific station or grid square}

Use the HTML pop-up tool within ArcGIS to see information for a location in map view (Figure 2). When this tool is selected, the user can click on a station or grid square to pull up information. Multiple popup windows can be opened simultaneously in order to compare values.

A feature class containing the location of cities, towns, and other populated places in Alaska is included in the download package (Populated Places). This is useful in identifying populated areas where information on tephra fall hazards may be in higher demand.

\section{FUTURE GOALS AND DATABASE ADDITIONS:}

The current version of this map-based compilation of tephra occurrence in Alaska will serve as a template for Alaska Volcano Observatory (AVO) geologists to record tephra occurrence data for active tephra studies in Alaska. We expect the database to expand as more tephra data become available either by publication or by AVO tephra fieldwork. Tephra occurrence data is now stored in GeoDIVA and a new version of the tephra occurrence map and geodatabase will be released when additional data warrants it. 


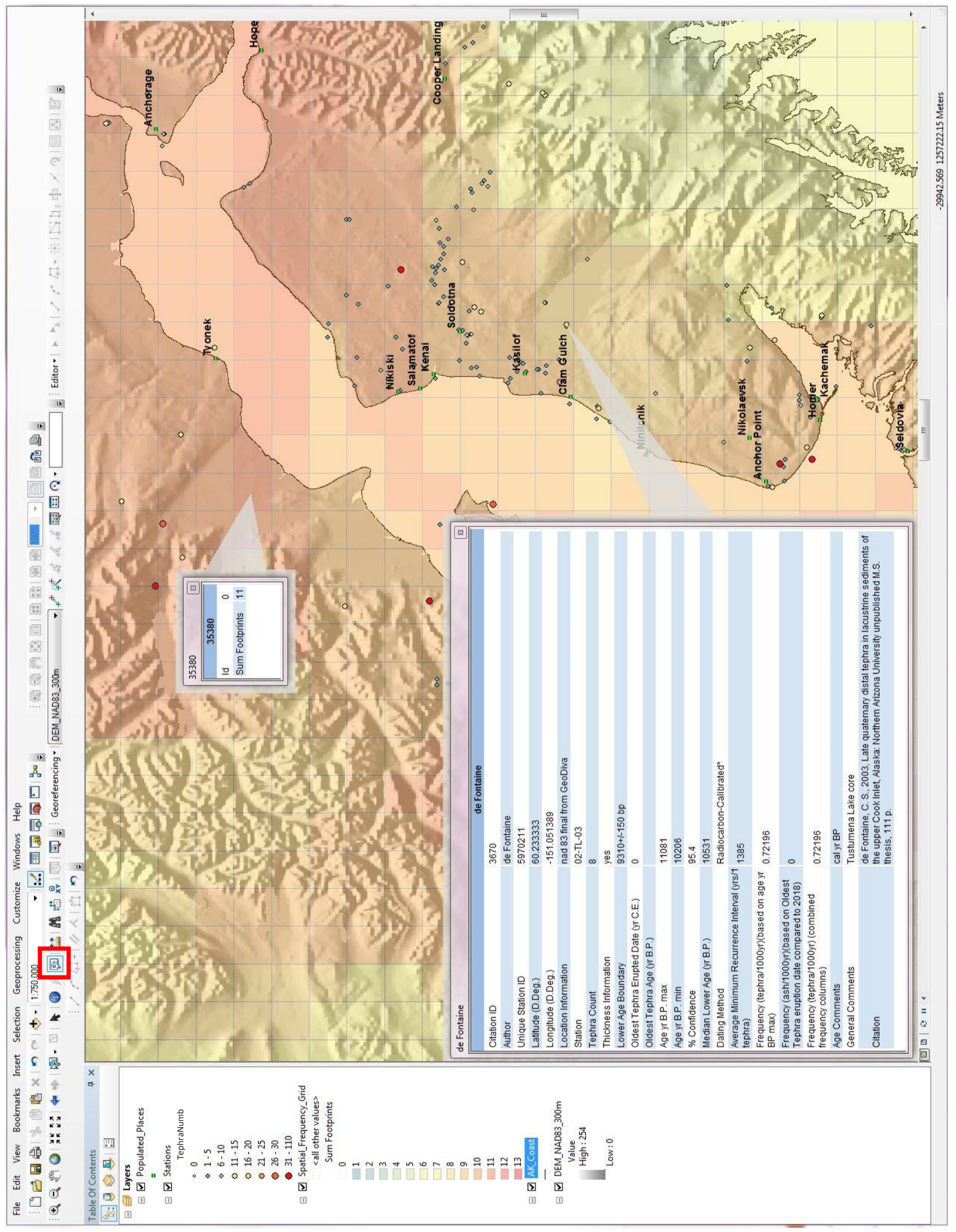

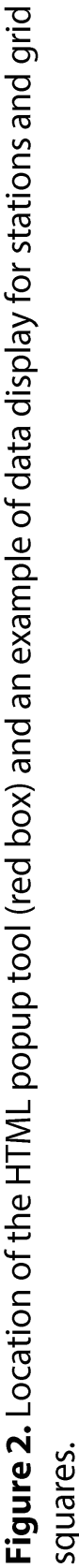




\section{REFERENCES CITED}

Cameron, C.E., 2004, Alaska GeoSurvey News - The geologic database of information on volcanoes in Alaska (GEODIVA): a comprehensive and authoritative source for volcanic information: Alaska

Division of Geological \& Geophysical Surveys Newsletter 2004-1, 8 p. http://doi.org/10.14509/14592

Krawiec, A.C., Kaufman, D.S., and Vaillencourt, D.A., 2013, Age models and tephrostratigraphy from two lakes on Adak Island, Alaska: Quaternary Geochronology, v. 18, p .41-53.

Mulliken, K.M., Schaefer, J.R., and Cameron, C.E., 2018, Geospatial distribution of tephra fall in Alaska: a geodatabase compilation of published tephra fall occurrences from the Pleistocene to the present: Alaska Division of Geological \& Geophysical Surveys Miscellaneous Publication 164, 46 p. http://doi.org/10.14509/29847

Ramsey, Bronk C. (2009). Bayesian analysis of radiocarbon dates. Radiocarbon, 51(1), 337-360.

Reimer, P.J., Bard, E., Bayliss, A., Warren Beck, J., Blackwell, P.G., Bronk Ramsey, C., Brown, D.M. Buck, C.E., Lawrence Edwards, R., Friedrich, M., Grootes, P.M., Guilderson, T.P., Haflidason, H., Hajdas, I., Hatte, C., Heaton, T.J., Hogg, A.G., Hughen K.A., Kaiser, K.F., Kromer, B., Manning, S.W., Reimer, R.W., Richards, D.A., Marian Scott, E., Southon, J.R., Turney, C.S.M. and J. van der Plicht 2013. Selection and treatment of data for radiocarbon calibration: an update to the international calibration (INTCAL) criteria. Radiocarbon 55(4):1923-1945.

\section{APPENDIX 1: REFERENCES FORTEPHRA OCCURRENCE DATA}

Sources of data compiled and included in the geodatabase.

Addison, J.A., Begét, J.E., Ager, T.A., and Finney, B.P., 2010, Marine tephrochronology of the Mt. Edgecumbe Volcanic Field, Southeast Alaska, USA: Quaternary Research, v. 73, n. 2, p. 277-292. http://doi.org/10.1016/j.yqres.2009.10.007

Axford, Yarrow, and Kaufman, D.S., 2004, Late glacial and Holocene glacier and vegetation fluctuations at Little Swift Lake, Southwestern Alaska, U.S.A.: Arctic, Antarctic, and Alpine Research, v. 36, n. 2, p. 139-146.

Bean, K.W., 1999, The Holocene eruptive history of Makushin Volcano, Alaska: University of Alaska Fairbanks unpublished M.S. thesis, Fairbanks, AK, 130 p.

Begét, J.E., Edwards, Mary, Hopkins, David, Keskinen, Mary, and Kukla, G. J., 1991a, Old Crow Tephra found at the Palisades of the Yukon, Alaska: Quaternary Research, v. 35, n. 2, p. 291-297.

Begét, J.E., Reger, R.D., Pinney, DeAnne, Gillispie, Tom, and Campbell, Kathy, 1991, Correlation of the Holocene Jarvis Creek, Tangle Lakes, Cantwell, and Hayes tephras in south-central and central Alaska: Quaternary Research, v. 35, n. 2, p. 174-189.

Begét, J.E., and Nye, C.J., 1994, Postglacial eruption history of Redoubt volcano, Alaska: in Miller, T. P. and Chouet, B. A., eds., The 1989-1990 eruptions of Redoubt Volcano, Alaska, Journal of Volcanology and Geothermal Research, v. 62, n. 1, p. 31-54.

Berger, G.W., 2003, Luminescence chronology of late Pleistocene loess-Paleosol and tephra sequences near Fairbanks, Alaska: in Westgate, J. A., ed., Special issue dedicated to Troy Pewe, Quaternary Research, v. 60, n. 1, p. 70-83. 
Bigelow, N., Reuther, J., Wooler, M., Wallace, K., 2015, Holocene Landscape and Paleoenvironments: Study Plan Section 13.5, Initial Study Report (Susitna-Watana Hydroelectric Project - FERC No. 14241).

Black, R. F., 1981, Late Quaternary climatic changes in the Aleutian Islands, Alaska: in Mahaney, W. C., ed., Quaternary paleoclimate, Norwich, U.K., Geoabstracts, Ltd., p. 47-62.

Blong, J.C., 2016, Prehistoric Landscape Use in the Central Alaska Range: Texas A\&M University Ph.D. dissertation, $421 \mathrm{p}$.

Boes, E., Van Daele, M., Moernaut, J., Schmidt, S., Jensen, B.J., Praet, N., Kaufman, D., Haeussler, P., Loso, M.G. and De Batist, M., 2017, Varve formation during the past three centuries in three large proglacial lakes in south-central Alaska: GSA Bulletin.

Bowers, P.M., 1979, The Cantwell ash bed, a Holocene tephra in the central Alaska Range, in Alaska

Division of Geological \& Geophysical Surveys, Short Notes on Alaskan Geology - 1978: Alaska

Division of Geological \& Geophysical Surveys Geologic Report 61E, p. 19-24. http://doi.org/10.14509/412

Carlson, J.K., 2016, Paleoearthquakes of the Past $~ 6000$ Years at the Dead Mouse Site, West-Central Denali Fault at the Nenana River, Alaska: University of Kentucky M.S. thesis, 73 p.

Carlson, L.J., and Finney, B.P., 2004, A 13,000-year history of vegetation and environmental change at Jan Lake, east-central Alaska: The Holocene, v. 14, n. 6, p. 818-827.

Carson, E.C., 1998, Holocene tephrochronology of the Cold Bay area, Southwest Alaska Peninsula: University of Wisconsin-Madison unpublished M.S. thesis, $178 \mathrm{p}$.

Carson, E.C., Fournelle, J.H., Miller, T.P., and Mickelson, D.M., 2002, Holocene tephrochronology of the Cold Bay area, southwest Alaska Peninsula: Quaternary Science Reviews, v. 21, n. 20-22, p. $2,213-2,228$.

Combellick, R.A., 1994, Investigation of peat stratigraphy in tidal marshes along Cook Inlet, Alaska, to determine frequency of 1964-style great earthquakes in the Anchorage region: Alaska Division of Geological \& Geophysical Surveys Report of Investigations RI 94-07, 24 p.

Conrad, James E., Edwin H. McKee, and Brent D. Turrin, 1992, Age of tephra beds at the Ocean Point Dinosaur Locality, North Slope, Alaska, based on K-Ar and ${ }^{40} \mathrm{Ar} /{ }^{39} \mathrm{Ar}$ analyses: U.S. Geological Survey Bulletin 1990-C.

Curtis, G.H., 1968, The stratigraphy of the ejecta from the 1912 eruption of Mount Katmai and Novarupta, Alaska, in Coats, R.R., Hay, R.L., and Anderson, C.A., eds., Studies in volcanology, Geological Society of America Memoir MWR 0116, p. 153-210.

Daigle, T.A., and Kaufman, D.S., 2009, Holocene climate inferred from glacier extent, lake sediment and tree rings at Goat Lake, Kenai Mountains, Alaska, USA: Journal of Quaternary Science, v. 24, n. 1, p. 33-45.

Davis, K., 2006, Volcanic, tectonic, and tsunamigenic events recorded in peats near Millers Landing, Homer, Alaska: University of Alaska, Fairbanks unpublished M.S. thesis, 135 p.

de Fontaine, C.S., 2003, Late quaternary distal tephra in lacustrine sediments of the upper Cook Inlet, Alaska: Northern Arizona University unpublished M.S. thesis, 111 p. 
de Fontaine, C.S., Kaufman, D.S., Anderson, R.S., Werner, Al, Waythomas, C.F., and Brown, T.A., 2007, Late Quaternary distal tephra-fall deposits in lacustrine sediments, Kenai Peninsula, Alaska: Quaternary Research, v. 68, p. 64-78. http://doi.org/10.1016/j.yqres.2007.03.006

DeRuwe, A.D., 2008, An 18,700 year record of tephra-fall frequency as recorded in peat cores recovered from the Kenai Peninsula, Alaska: Alaska Pacific University M.S. thesis, 28 p.

Dilley, T.E., 1988, Holocene tephra stratigraphy and pedogenesis in the middle Susitna River valley, Alaska: University of Alaska, Fairbanks unpublished M.S. thesis, 97 p.

Dixon, J.E., and Smith, G.S., 1990, A regional application of tephrochronology in Alaska: Geological Society of America Centennial Special Volume, v. 4, p. 383-398.

Dreher, S.T., 2002, The physical volcanology and petrology of the $3400 \mathrm{yBP}$ caldera-forming eruption of Aniakchak volcano, Alaska: Fairbanks, University of Alaska Fairbanks, Ph.D. dissertation, 174 p.

Dreher, S.T., Eichelberger, J.C., and Larsen, J.F., 2005, The petrology and geochemistry of the Aniakchak caldera-forming ignimbrite, Aleutian arc, Alaska: Journal of Petrology, v. 46, p. 1,7471,768 .

Dunning, H., 2011, Extending the Applications of Tephrochronology in Northwestern North America: University of Alberta M.S. Thesis, $187 \mathrm{p}$.

Edwards, M.E., and McDowell, P.F., 1991, Interglacial deposits at Birch Creek, northeast Interior Alaska: Quaternary Research, v. 35, p. 41-52.

Elias, S.E., Hamilton, T.D., Edwards, M.E., Beget, J.E., Krumhardt, A.P., and Lavoie, C., 1999, Late Pleistocene environments of the western Noatak basin, northwestern Alaska: Geological Society of America Bulletin, v. 111, p. 769-789.

Evans, M.E., Jensen, B.J.L., Kravchinsky, V.A., and Froese, D.G., 2011, The Kamikatsura event in the Gold Hill loess, Alaska: Geophysical Research Letters, v. 38, 5 p. http://dx.doi.org/10.1029/2011GL047793

Feinberg, A.E., 2000, Evidence of Holocene glacial activity from the Ahklun Mountains, southwestern Alaska: Mount Holyoke College BA thesis, 83 p.

Fierstein, Judy, and Hildreth, Wes, 1992, The plinian eruptions of 1912 at Novarupta, Katmai National Park, Alaska: Bulletin of Volcanology, v. 54, n. 8, p. 646-684.

Fierstein, Judy, and Wilson, C.J.N., 2005, Assembling an ignimbrite: Compositionally defined eruptive packages in the 1912 Valley of Ten Thousand Smokes ignimbrite, Alaska: Geological Society of America Bulletin, v. 117, n. 7/8, p. 1,094-1,107.

Fierstein, Judy, 2007, Explosive eruptive record in the Katmai region, Alaska Peninsula: an overview: Bulletin of Volcanology, v. 69, n. 5, p. 469-509.

http://doi.org/10.1007/s00445-006-0097-y

Fontana, M.R., 1988, Holocene tephrochronology of the Matanuska Valley, Alaska: University of Alaska Fairbanks M.S. thesis, 99 p.

Fraser, T.A., and Burn, C.R., 1997, On the nature and origin of "muck" deposits in the Klondike area, Yukon territory: Canadian Journal of Earth Sciences, v. 34, p. 1,333-1,344. 
Froese, D.G., Barendregt, R.W., Enkin, R.J., and Baker, J., 2000, Paleomagnetic evidence for multiple late Pliocene-early Pleistocene glaciations in the Klondike area, Yukon Territory: Canadian Journal of Earth Sciences, v. 37, n. 6, p. 863-877.

Froese, D.G., Westgate, John, Preece, S.J., and Storer, John, 2002, Age and significance of the late Pleistocene Dawson Tephra in eastern Beringia: Quaternary Science Reviews, v. 21, n. 20-22, p. $2,137-2,142$.

Froese, D.G., Smith, D.G., Westgate, J.A., Ager, T.A., Preece, S.J., Sandhu, A., Enkin, R.J., and Weber, F., 2003, Recurring middle Pleistocene outburst floods in east-central Alaska: Quaternary Research, v. 60 , n. 1, p. 50-62, http://doi.org/10.1016/S0033-5894(03)00090-5

Froese, D.G., Westgate, J.A., and Alloway, B.V., eds., 2005, Field trip guide for the International Field Conference and Workshop on Tephrochronology and Volcanism, Dawson City, Yukon Territory, Canada, July 31 - August 8, 2005: Institute of Geological and Nuclear Sciences science report 2005/26, 132 p.

Funk, J.M., 1973, Late Quaternary geology of Cold Bay, Alaska, and vicinity: University of Connecticut unpublished M.S. thesis, $45 \mathrm{p}$.

Gardner, C.A., Neal, C.A., Waitt, R.B., and Janda, R.J., 1994, Proximal pyroclastic deposits from the 1989-1990 eruption of Redoubt volcano, Alaska - stratigraphy, distribution, and physical characteristics, in Miller, T. P. and Chouet, B. A., eds., The 1989-1990 eruptions of Redoubt Volcano, Alaska, Journal of Volcanology and Geothermal Research, v. 62, n. 1.

Gardner, J.E., Burgisser, Alain, and Stelling, Pete, 2007, Eruption and deposition of the Fisher Tuff (Alaska): evidence for the evolution of pyroclastic flows: Journal of Geology, v. 115, p. 417-435.

Hancock, J. R., 2002, A Holocene reconstruction for Anchorage, Alaska: Mount Holyoke College unpublished B.A. thesis, $190 \mathrm{p}$.

Höfle, C., Ping, C.L., 1996, Properties and soil development of late-Pleistocene paleosols from Seward Peninsula, northwest Alaska: Geoderma, v. 71, p. 219-243.

Höfle, C., Edwards, M.E., Hopkins, D.M., Mann, D.H., and Ping, Chien-Lu, 2000, The full-glacial environment of the Northern Seward Peninsula, Alaska, reconstructed from the 21,500-year-old Kitluk paleosol: Quaternary Research, v. 53, n. 2., p. 143-153. http://doi.org/10.1006/qres.1999.2097

Houghton, B.F., Wilson, C.J. N., Fierstein, J., and Hildreth, W., 2004, Complex proximal deposition during the Plinian eruptions of 1912 at Novarupta, Alaska: Bulletin of Volcanology, v. 66, n. 2, p. 95-113.

Hughes, O.L., Harington, C.R., Schweger, C.E., and Matthews, J.V. Jr., 1987, Ash Bend Section, in Morison, S.R, and Smith, C.A.S., eds., Guidebook to Quaternary research in Yukon: XII INQUA Congress, Ottawa, Canada, National Research Council, Ottawa, Ontario, p. 50-53.

Jackson Jr., L.E., Froese, D.G., Telka, A.M., Westgate, J.A., Preece, S.J., Storer, J.E., and Huscroft, C.A., 2002, Late Cenozoic geology, Ancient Pacific Margin NATMAP Project, report 5: paleoecology and proxy climatic change records, south Klondike placer region, Yukon Territory: Geological Survey of Canada, Current Research, 2002-A2, 16 p. 
Jackson Jr., L.E., Froese, D.G., Huscroft, C.A., Nelson, F.E., Westgate, J.A., Telka, A.M., Shimamura, K., and Rotheisler, P.N., 2009, Surficial geology and late Cenozoic history of the Stewart River and northern Stevenson Ridge map areas, west-central Yukon Territory: Geological Survey of Canada, Open File 6059, 414 p., 1 CD-ROM.

Jensen, B.J.L., 2007, Tephrochronology of Middle to Late Pleistocene Loess in Eastcentral Alaska: University of Alberta M.S. thesis, $120 \mathrm{p}$.

Jensen, B.J.L., Preece, S.J., Lamothe, Michel, Pearce, N.J.G., Froese, D.G., Westgate, J.A., Schaefer, Janet, and Beget, Jim, 2011, The variegated (VT) tephra: A new regional marker for middle to late marine isotope stage 5 across Yukon and Alaska: Quaternary International, v. 246, p. 312-323. http://doi.org/10.1016/j.quaint.2011.06.028

Kassel, C.M., 2009, Lacustrine evidence from Mother Goose Lake of Holocene geothermal activity at Mount Chiginagak, Alaska Peninsula: Northern Arizona University unpublished M.S. thesis, 138 p.

Kathan, K.M., 2004, Intrabasin variability of volcanic ash stratigraphy in a small kettle lake; Lorraine Lake, Anchorage, Alaska: Mount Holyoke College unpublished B.A. thesis, 146 p.

Kathan, Kasey, 2006, Late Holocene climate fluctuations at Cascade Lake, northeastern Ahklun Mountains, southwestern Alaska: Northern Arizona University M.S. thesis, 112 p.

Kaufman, D.S., Manley, W.F., Forman, S.L., and Layer, P.W., 2001, Pre-late-Wisconsin glacial history, coastal Ahklun Mountains, Southwestern Alaska: new amino acid, thermoluminescence, and 40Ar/39Ar results, in Elias, S.A. and Brigham, G.J., eds., Beringian paleoenvironments: festschrift in honour of D.M. Hopkins: Quaternary Science Reviews, v. 20, n. 1, p. 337-352.

Kaufman, D.S., Manley, W.F., Wolfe, A.P., Hu, F.S., Preece, S.J., Westgate, J.A., Forman, S.L., 2001, The last interglacial to glacial transition, Togiak Bay, southwestern Alaska: Quaternary Research v. 55, p. 190-202.

Kaufman, D.S., Jensen, B.J.L., Reyes, A.V., Schiff, C.J., Froese, D.G., and Pearce, N.J.G., 2012, Late Quaternary tephrostratigraphy, Ahklun Mountains, SW Alaska: Journal of Quaternary Science, v. 27, n. 4, p. 344-359. http://doi.org/10.1002/jqs.1552 [See linked files on internal page]

Kiriyanov, V.Y., and Miller, T.P., 1997, Volcanic ashes of Adak Island, Aleutian Islands, Alaska: Volcanology and Seismology, v. 19, n. 1, p. 52-77.

Krawiec, A.C., Kaufman, D.S., and Vaillencourt, D.A., 2013, Age models and tephrostratigraphy from two lakes on Adak Island, Alaska: Quaternary Geochronology, v. 18, p .41-53.

LaBrecque, T.S., and Kaufman, D.S, 2016, Holocene glacier fluctuations inferred from lacustrine sediment, Emerald Lake, Kenai Peninsula, Alaska: Quaternary Research, v. 85, n. 1, p. 34-43.

Lakeman, T.R., Clague, J.J., Menounos, B., Osborn, G.D., Jensen, B.J.L., Froese, D.G., 2008, Holocene tephras in lake cores from northern British Columbia, Canada: Canadian Journal of Earth Science, v. 45 , p. $935-947$.

Lemke, K.J., 2000, Holocene tephrostratigraphy, southern Kenai Peninsula, Lower Cook Inlet, Alaska: Utah State University unpublished M.S. thesis, 96 p. 
Lerner, A.H., 2010, Eruption dynamics of the 7.7 ka Driftwood pumice-fall, Makushin Volcano, Alaska: Proceedings of the 23rd Annual Keck Research Symposium in Geology, April 2010, p. 348353.

Levy, L.B., 2002, A record of late Holocene glacier fluctuations, Ahklun Mountains, southwestern Alaska: Northern Arizona University M.S. thesis, 71 p.

Levy, L.B., Kaufman, D.S., and Werner, A., 2004, Holocene glacier fluctuations, Waskey Lake, northeastern Ahklun Mountains, southwestern Alaska: The Holocene, v. 14, p. 185-193.

MacIntosh, G.D., [n.d.], The Calendric Dating and Seasonality of the White River Ash: University of Alaska Fairbanks.

Monteath, A.J., van Hardenbroek, M., Davies, L.J., Froese, D.G., Langdon, P.G., Xu, X., and Edwards, M.E., 2017, Chronology and glass chemistry of tephra and cryptotephra horizons from lake sediments in northern Alaska, USA: Quaternary Research, v. 88, p. 1-10.

Matheus, Paul, Begét, J.E., Mason, O.K., and Gelvin-Reymiller, Carol, 2003, Late Pliocene to late Pleistocene environments preserved at the Palisades Site, central Yukon River, Alaska: in Westgate, J.A., ed., Special issue dedicated to Troy Pewe: Quaternary Research, v. 60, n. 1, p. 33-43.

Matthews, J.V., Westgate, J.A., Overnden, Lynn, Carter, L.D., and Fouch, Thomas, 2003, Stratigraphy, fossils, and age of sediments at the upper pit of the Lost Chicken gold mine: new information on the late Pliocene environment of east central Alaska: Quaternary Research, v. 60, n. 1, p. 9-18.

McKay, N.P., and Kaufman, D.S., 2009, Holocene climate and glacier variability at Hallet and Greyling Lakes, Chugach Mountains, south-central Alaska: Journal of Paleolimnology, v. 41, p. 143-159.

Morison, S.R., Mougeot, Charlotte, and Walton, Lori, 1998, Surficial geology and sedimentology of Garner Creek, Ogilvie and Matson Creek map areas, western Yukon Territory: Exploration and Geological Services Division, Yukon Region, Indian and Northern Affairs Canada Open-File 1998$1,87 \mathrm{p}$.

Muhs, D.R., Ager, T.A., and Begét, J.E., 2001, Vegetation and paleoclimate of the last interglacial period, central Alaska: Quaternary Science Reviews, v. 20, p. 41-61.

Mulliken, K.M., 2016, Holocene volcanism and human occupation in the middle Susitna River Valley, Alaska: University of Alaska Fairbanks M.A. thesis, 234 p.

Naeser, N.D., Westgate, J.A., Hughes, O.L., and Pewe, T.L., 1982, Fission-track ages of late Cenozoic distal tephra beds in the Yukon Territory and Alaska: Canadian Journal of Earth Sciences [Journal Canadien des Sciences de la Terre], v. 19, n. 11, p. 2,167-2,178.

Nayudu, Y.R., 1964, Volcanic ash deposits in the Gulf of Alaska and problems of correlation of deepsea ash deposits: Marine Geology, v. 1, n. 3, p. 194-212.

Nicholson, R.S., 2003, The 1931 eruption of Aniakchak volcano, Alaska: University of Alaska Fairbanks unpublished M.S. thesis, $270 \mathrm{p}$.

Nybakken, B.H., and Reeder, W.G., 1965, A soil sequence from southwestern Umnak Island, Alaska: Northwest Science, v. 39, n. 3, p. 104-117.

Okuno, M., Wada, K., Nakamura, T., Gualtieri, L., Sarata, B., West, D., and Torii, M., 2012, Holocene Tephra Layers on the Northern Half of Adak Island in the West-Central Aleutian Islands, Alaska, 
in West, D., Hatfield, V., Wilmerding, E., Lefevre, C. and Gualtieri, L, eds., The People Before: The Geology, Paleoecology and Archaeology of Adak Island, Alaska: Oxford, UK, British Archaeological Reports, p. 61-75.

Okuno, Mitsuru, Izbekov, Pavel, Nicolaysen, K.P., Sato, Eiichi, Nakamura, Toshio, Savinetsky, A.B., Vasyukov, Dmitrii, Krylovich, O.A., Khasanov, Bulat, Miranda, Jonathan, Persico, Lyman, Hatfield, Virginia, West, D.L., and Bruner, K.M., 2017, AMS radiocarbon dates on peat section related with tephra and archaeological sites in Carlisle Island, the Islands of Four Mountains, Alaska: Radiocarbon, v. 59, no. 6, p. 1,771-1,778.

Palagushkina, O., Wetterich, S., Biskaborn, B.K., Nazarova, L., Schirrmeister, L., Lenz, J., Schwamborn, G. and Grosse, G., 2017, Diatom records and tephra mineralogy in pingo deposits of Seward Peninsula, Alaska: Palaeogeography, Palaeoclimatology, Palaeoecology, v. 479, p. 1-15.

Pewe, T.L., 1975, Quaternary geology of Alaska: U.S. Geological Survey Professional Paper PP 0835, 145 p., 3 sheets, scale 1:5,000,000.

Pewe, T.L., 1975, Quaternary stratigraphic nomenclature in unglaciated central Alaska: U.S. Geological Survey Professional Paper PP 0862, 32 p.

Pewe, T.L., and Reger, R.D., 1983, Guidebook to Permafrost and Quaternary Geology along the Richardson and Glenn Highways between Fairbanks and Anchorage, Alaska: Alaska Division of Geological \& Geophysical Surveys Guidebook 1, 263 p., 1 sheet, scale 1:250,000. http://doi.org/10.14509/263

Pewe, T.L., Westgate, J.A., Preece, S.J., Brown, P.M., and Leavitt, S.W., 2009, Late Pliocene Dawson Cut forest bed and new tephrochronological findings in the Gold Hill Loess, east-central Alaska: Geological Society of America Bulletin, v. 121, n. 1-2, p. 294-320. http://doi.org/10.1130/B26323.1 Pinney, D.S., 1993, Late Quaternary glacial and volcanic stratigraphy near Windy Creek, Katmai National Park, Alaska: University of Alaska Fairbanks unpublished M.S. thesis, 185 p.

Preece, S.J., Westgate, J.A., Stemper, B.A., and Pewe, T.L., 1999, Tephrochronology of late Cenozoic loess at Fairbanks, central Alaska: Geological Society of America Bulletin, v. 111, n. 1, p. 71-90.

Reger, R.D., Pinney, D.S., Burke, R.M., and Wiltse, M.A., 1995, Catalog and initial analyses of geologic data related to middle and late Quaternary deposits, Cook Inlet region, Alaska: Alaska Division of Geological \& Geophysical Surveys Report of Investigations RI 95-06, 188 p., 6 sheets, scale $1: 250,000$.

Reinink-Smith, L.M., 1990, Relative frequency of Neogene volcanic events as recorded in coal partings from the Kenai lowland, Alaska: a comparison with deep-sea core data: Geological Society of America Bulletin, v. 102, n. 6, p. 830-840.

Reinink-Smith, L. M., 1995, Tephra layers as correlation tools of Neogene coal-bearing strata from the Kenai Lowland, Alaska: Geological Society of America Bulletin, v. 107, n. 3, p. 340-353.

Reyes, A.V., Froese, D.G., and Jensen, B.L., 2010, Permafrost response to last interglacial warming: field evidence from non-glaciated Yukon and Alaska: Quaternary Science Reviews, v. 29, n. 23024, p. 3,256-3,274. http://doi.org/10.1016/j.quascirev.2010.07.013

Reyes, A.V., Jensen, B.L., Zazula, G.D., Ager, T.A., Kuzmina, Svetlana, La Farge, Catherine, and Froese, D.G., 2010, A late-Middle Pleistocene (Marine Isotope Stage 6) vegetated surface buried by 
Old Crow tephra at the Palisades, interior Alaska: Quaternary Science Reviews, v. 29, n. 5-6.

http://doi.org/10.1016/j.quascirev.2009.12.003

https://www.avo.alaska.edu/downloads/get file.php?id=4081

Reyes, A.V., Zazula, G.D., Kuzmina, S., Ager, T.A., Froese, D.G., 2011, Identification of last interglacial deposits in eastern Beringia: a cautionary note from the Palisades, interior Alaska: Journal of Quaternary Science, v. 26, n. 3, p. 345-352.

Riehle, J.R., 1985, A reconnaissance of the major Holocene tephra deposits in the upper Cook Inlet region, Alaska: Journal of Volcanology and Geothermal Research, v. 26, n. 1-2, p. 37-74.

Riehle, J.R., Ager, T.A., Reger, R.D., Pinney, D.S., and Kaufman, D.S., in press, Stratigraphic and compositional complexities of the late Quaternary Lethe tephra in south-central Alaska: Quaternary International, 19 p. $\quad$ https://www.avo.alaska.edu/downloads/get_file.php?id=888

Riehle, J.R., Champion, D.E., Brew, D.A., Lanphere, M.A., 1992, Pyroclastic deposits of the Mount Edgecumbe volcanic field, southeast Alaska: eruptions of a stratified magma chamber: Journal of Volcanology and Geothermal Research, v.53, n. 1-4, p. 117-143.

Riehle, J.R., Dumond, D.E., Meyer, C.E., and Schaaf, J.M., 2000, Tephrochronology of the Brooks River Archaeological District, Katmai National Park and Preserve, Alaska: what can and cannot be done with tephra deposits, in McGuire, W.J., Griffiths, D.R., Hancock, P.L., and Stewart, I.S., eds., The archaeology of geological catastrophes, Geological Society, London Special Publication 171, p. 245-266.

Riehle, J.R., Mann, D.H., Peteet, D.M., Engstrom, D.R., Brew, D.A., and Meyer, C.E., 1992, The Mount Edgecumbe tephra deposits: a marker horizon in southeastern Alaska near the PleistoceneHolocene boundary: Quaternary Research, v. 37, n. 2, p. 183-202.

Riehle, J.R., Meyer, C.E., Ager, T.A., Kaufman, D.S., and Ackerman, R.E., 1987, The Aniakchak tephra deposit, a late Holocene marker horizon in western Alaska, in Hamilton, T.D. and Galloway, J.P., eds., Geologic studies in Alaska by the U.S. Geological Survey during 1986: U.S. Geological Survey Circular C 0998, p. 19-22. https://www.avo.alaska.edu/downloads/get file.php?id=4671

Riehle, J.R., Meyer, C.E., and Miyaoka, R.T, 1999, Data on Holocene Tephra (Volcanic Ash) Deposits in the Alaska Peninsula and Lower Cook Inlet Region of the Aleutian Volcanic Arc, Alaska: U.S. Geological Survey Open-File Report OF 99-0135, 5 p.

https://www.avo.alaska.edu/downloads/get file.php?id=76

Riehle, J.R., Waitt, R.B., Meyer, C.E., and Calk, L.C., 1998, Age of formation of Kaguyak Caldera, eastern Aleutian Arc, Alaska, estimated by tephrochronology, in Gray, J.E. and Riehle, J.R., eds., Geologic studies in Alaska by the U.S. Geological Survey, 1996: U.S. Geological Survey Professional Paper PP 1595, p. 161-168.

Riehle, J.R., Yount, M.E., and Miller, T.P., 1987, Petrography, chemistry, and geologic history of Yantarni volcano, Aleutian volcanic arc, Alaska: U.S. Geological Survey Bulletin B 1761, 27 p., 1 sheet, scale 1:63,360.

Romick, J.D., Kay, S.M., and Kay, R.W., 1992, The influence of amphibole fractionation on the evolution of calc-alkaline andesite and dacite tephra from the central Aleutians, Alaska: Contributions to Mineralogy and Petrology, v. 112, n. 1, p. 101-118. 
Sandhu, A.S., Westgate, J.A., Preece, S.J., and Froese, D.G., 2001, Glass-fission-track ages of late Cenozoic distal tephra beds in the Klondike district, Yukon Territory, in Emond, D.S., and Weston, L.H, Yukon exploration and geology 2000, 2001: Exploration and Geological Services Division, Yukon, Indian and Northern Affairs Canada, p. 247-256.

Schaefer, J.R.G., 2002, Stratigraphy, major oxide geochemistry, and 40Ar/39Ar geochronology of a tephra section near Tok, Alaska: University of Alaska Fairbanks unpublished M.S. thesis, $62 \mathrm{p}$.

Schiff, C.J., 2007, A modern survey and Holocene record of lake water and diatom isotopes from south Alaska: M.S. Thesis, Flagstaff, Arizona, Northern Arizona University, 103 p.

Schiff, C.J., Kaufman, D.S., Wallace, K.L., and Ketterer, M.E., 2010, An improved proximal tephrochronology of Redoubt Volcano, Alaska: Journal of Volcanology and Geothermal Research, v. 193, no. 3/4, p. 203-214. http://doi.org/10.1016/j.jvolgeores.2010.03.015

Schiff, C.J., Kaufman, D.S., Wallace, K.L., Werner, A., Ku, T.L., and Brown, T.A., 2008, Modeled tephra ages from lake sediments, base of Redoubt Volcano, Alaska: Quaternary Geochronology, v. 3, p. 56-67.

Scholl, D.W., Creager, J.S., Boyce, R.E., Echols, R.J., Fullam, T.J., Grow, J.A., Koizumi, Itaru, Lee, H.J., Ling, H.Y., Stewart, R.J., Supko, P.R., and Worley, S.L., 1973, Site 191, in Supko, P.R., ed., Initial Reports of the Deep Sea Drilling Project, Volume 19: Washington, Government Printing Office, p. 413-461.

Siebert, L., Glicken, H., and Kienle, J., 1989, Debris avalanches and lateral blasts at Mount St. Augustine volcano, Alaska: National Geographic Research, v. 5, n. 2, p. 232-249.

Siebert, Lee, Begét, J.E., and Glicken, Harry, 1995, The 1883 and late-prehistoric eruptions of Augustine volcano, Alaska: Journal of Volcanology and Geothermal Research, v. 66, n. 1, p. 367395.

Stilwell, K.B., 1995, Late Quaternary glacial geology, shoreline morphology, and tephrochronology of the Iliamna/ Naknek/ Brooks Lake area, Southwestern Alaska: Utah State University unpublished M.S. thesis, $176 \mathrm{p}$.

Tannenbaum, T.G., 1996, Holocene tephra stratigraphy on northern Kodiak Island, Alaska: University of Alaska Fairbanks M.S. thesis, 165 p.

VanderHoek, R., and Myron, R., 2004, An archaeological overview and assessment of Aniakchak National Monument and Preserve: U.S. National Park Service Research/Resources Management Report AR/CRR-2004-47.

Waitt, R.B., and Begét, J.E., 2009, Volcanic processes and geology of Augustine Volcano, Alaska: U.S.

Geological Survey Professional Paper 1762, 78 p., 2 plates, scale 1:25,000. http://pubs.usgs.gov/pp/1762/

Waitt, R.B., 2010, Ejecta and landslides from Augustine Volcano before 2006, in Power, J.A., Coombs, M.L., and Freymueller, J.T., eds., The 2006 eruption of Augustine Volcano, Alaska: U.S. Geological Survey Professional Paper 1769, p. 297-319 http://pubs.usgs.gov/pp/1769/chapters/p1769 chapter13.pdf

Wallace, K.L., Neal, C.A., and McGimsey, R.G., 2010, Timing, distribution, and character of tephra fall from the 2005-2006 eruption of Augustine Volcano, in Power, J.A., Coombs, M.L., and 
Freymueller, J.T., eds., The 2006 eruption of Augustine Volcano, Alaska: U.S. Geological Survey Professional Paper 1769, p. 187-217.

http://pubs.usgs.gov/pp/1769/chapters/p1769 chapter09

Wallace, K.L., Coombs, M.L., Hayden, L.A., and Waythomas, C.F., 2014, Significance of a near-source tephra-stratigraphic sequence to the eruptive history of Hayes Volcano, south-central Alaska: U.S. Geological Survey Scientific Investigations Report 2014-5133, 32 p. http://pubs.usgs.gov/sir/2014/5133/

Ward, B.C., Bond, J.D., Froese, D., and Jensen, B., 2008, Old Crow tephra (140+/-10 ka) constrains penultimate Reid glaciation in central Yukon Territory: Quaternary Science Reviews, v. 27, p. $1,909-1,915$.

Waythomas, C.F., 1990, Quaternary geology and late-Quaternary environments of the Holitna Lowland and Chuilnuk-Kiokluk Mountains region, interior southwestern Alaska: University of Colorado Ph.D. dissertation, 305 p.

Waythomas, C.F., 1999, Stratigraphic framework of Holocene volcaniclastic deposits, Akutan Volcano, east-central Aleutian Islands, Alaska: Bulletin of Volcanology, v. 61, n. 3, p. 141-161.

West, K.D., and J.A. Donaldson, 2001, Resedimentation of the late Holocene White River tephra, Yukon Territory and Alaska: Yukon exploration and geology, p. 239-247.

Westgate, J.A., Hamilton, T.D., and Gorton, M.P., 1983, Old Crow tephra: a new late Pleistocene stratigraphic marker across North-central Alaska and western Yukon Territory: Quaternary Research, v. 19, n. 1, p. 38-54.

Westgate, J.A., Preece, S.J., and Pewe, T.L., 2003, The Dawson Cut Forest Bed in the Fairbanks area, Alaska, is about two million years old, in Westgate, J. A., ed., Special issue dedicated to Troy Pewe, Quaternary Research, v. 60, n. 1, p. 2-8.

Westgate, J.A., Preece, S.J., Froese, D.G., Pearce, N.J.G., Roberts, R.G., Demuro, M., Hart, W.K., and Perkins, W., in press, Changing ideas on the identity and stratigraphic significance of the Sheep Creek tephra beds in Alaska and the Yukon Territory, northwestern Alaska: Quaternary International, 27 p. http://doi.org/10.1016/j.quaint.2007.03.009

Westgate, J.A., Preece, S.J., Froese, D.G., Telka, A.M., Storer, J.E., Pearce, N.J.G., Enkin, R.J., Jackson, L.E. Jr., LeBarge, W., and Perkins, W.T., 2009, Gold Run Tephra: a middle Pleistocene stratigraphic and paleoenvironmental marker across west-central Yukon Territory, Canada: Canadian Journal of Earth Sciences, v. 46, n. 6, p. 465-478. http://doi.org/10.1139/E09-029

Westgate, J.A., Pearce, G.W., Preece, S.J., Schweger, C.E., Morlan, R.E., Pearce, N.J.G., and Perkins, T.W., 2013, Tephrochronology, magnetostratigraphy and mammalian faunas of Middle and Early Pleistocene sediments at two sites on the Old Crow River, northern Yukon Territory, Canada: Quaternary Research, v. 79, n. 1, p. 75-85.

Wilcox, P.S., 2017, 60,000 year climate and vegetation history of Southeast Alaska: Fairbanks, University of Alaska Fairbanks Ph.D. dissertation, 101 p.

Winer, G.S., 2001, St. Paul Island, Pribilof Islands, Alaska; geology, volcanic evolution, and volcanic hazards: Montana State University unpublished M.S. thesis, 169 p. 
Wong, L.J., 2004, Physical volcanology of a sub-plinian and phreatomagmatic eruption at Okmok Volcano, Alaska: implications for explosive mafic volcanism: University of Alaska Fairbanks unpublished M.S. thesis, $117 \mathrm{p}$.

Yeend, W.E., 1977, Tertiary and Quaternary deposits at the Palisades, central Alaska: Journal of Research of the United States Geological Survey, v. 5, n. 6, p. 747-752.

Zander, P.D., Kaufman, D.S., Kuehn, S.C., Wallace, K.L., and Anderson, R.S., 2013, Early and late Holocene glacial fluctuations and tephrostratigraphy, Cabin Lake, Alaska: Journal of Quaternary Science, v. 28, n. 8, p. 761-771. http://doi.org/10.1002/jqs.2671 